\title{
似顔絵生成のための顔と瞳の輪郭抽出方式
}

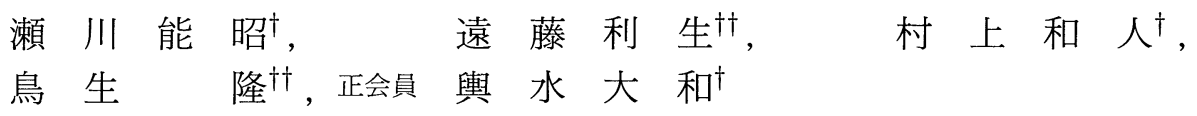

\section{A Method for Extracting Faces and Irises for Facial Caricaturing}

\author{
Yoshiaki Segawa $^{\dagger}$, Toshio Endoh ${ }^{\dagger \dagger}$, Kazuhito Murakami ${ }^{\dagger}$, \\ Takashi Toriu ${ }^{\dagger \dagger}$ and Hiroyasu Koshimizu ${ }^{\dagger}$
}

\begin{abstract}
As the first step for developing the system that generates facial caricatures automatically, we developed a method of extracting the facial region and the irises. The facial region is extracted by a thresholding procedure in which the threshold is selected based on the degree of the coincidence between the outermost edges and the region boundary. Then, another type of thresholding is performed in the facial region, and the boundary of the binary image is detected. Next, using a Hough transform, a number of small circles are detected as candidates for the irises. On the basis of the geometrical relation between the left and right irises, a pair of circles are finally selected as irises. We experimented with 30 face images. The facial regions were successfully extracted for all of images and irises were successfully recognized for 29 images. It was found that the unsuccessful case could be recovered by a verification process.
\end{abstract}

\section{1. まえ がき}

似顔絵師システム $\mathrm{PICASSO}^{122)}$ では, 個々人の顔や 顔部品の輪郭と, 多数の人の顔や顔部品の輪郭の平均 との差異を特徵と考え, この特徵を強調することに よって似顔絵を作成している。これまで顔や顔部品の 輪郭は手入力で行ってきたが, 今回, それを自動化す る検討を行った。

本稿ではその第一ステップとして顔の輪郭と瞳の輪 郭抽出に焦点を置く．顔部品の中で特に瞳を選んだ理 由は, 人間の顔の認知において瞳は重要な位置を占め
ており, 似顔絵における顔記述において, 瞳を正確か つ安定に抽出することは必要不可欠であるからである. また，画像処理の観点から，抽出した瞳を位置の基準 とすれば，他の顔部品の抽出が容易になると考えたか らである。

これまでに, 最小 2 乗法によって瞳を抽出する方法 ${ }^{3)}$ が提案されているが, 最小 2 乗法は瞳以外に起因する エッジ等のノイズの影響を受けやすいので, 瞳がほぼ 画像の全域を占めるように画像を入力することによっ て精度を上げている，似顔絵師システムでは顔全体を 処理する必要があるので, この方法は適切ではない.

キーワード：似顔絵生成, 顔の初期記述, 外側エッジ, 2 值化閾值処理, Hough 変換

1996 年 8 月, 国際会議 PRICAI で発表

1997 年 4 月 7 日受付, 1997 年 8 月 13 日再受付

† 中京大学 情報科学部 (广 470-03 豊田市貝津町床立 101, TEL 0565-45-0971)

†† 株式会社 富士通研究所 ( $\bar{T}$ 470-03 豊田市貝津町床立 101, 中京大学人工知能高等研究所内 TEL 0565-43-0063)

† School of Computer and Cognitive Sciences, Chukyo University (101 Tokodate, Kaizu-cho, Toyota-shi, Aichi 470-03, Japan)

†† Fujitsu Laboratories Ltd. (101 Tokodate, Kaizu-cho, Toyota-shi, Aichi 470-03, Japan) 
筆者らは,ノイズの影響を受けにくい Hough 変換に 基づいて瞳を抽出することとした。一般に Hough 変 換では複数の解が得られるが, 本稿では後処理として 2 つの瞳の位置関係に関する知識を利用して最適な解 を選択するようにした。

処理手順の概要は以下の通りである。まず, 無地な 背景の基で画像を入力することとし，2 值化処理およ び穴埋め処理によって顔領域を抽出する. 次に, 顔領 域を対象として再び 2 值化処理を行い, 2 回目の 2 值化 処理における図と地の境界をエッジとして円の Hough 変換および後処理によって 2 つの瞳を抽出する.

ここで問題となるのは, これらの 2 值化処理におい て閾值をどのように選択するかということである．1 回目の 2 值化処理では, 背景は一様であるが顔の内部 では濃淡の変化が大きいため, 濃度ヒストグラムの谷 の部分を閾值とするのは適切ではない。.また， 2 值化 したときの境界と画像を微分して得られるエッジがで きるだけ一致するように閾値を選択する手法 ${ }^{5}$ が提案 されているが, この方法も, 顔の内部に多数のエッジ が存在するため, 選択される閾值が背景と顔領域を分 けるための閾值としては適切でない，そこで, 本稿で は, 最も外側のエッジ4) (外側エッジ) だけに着目し， それが 2 值化したときの境界とできるだけ一致するよ うに閾值を選択する新たな手法を提案する。具体的に は原画像を 2 值化して得られる 2 值画像の境界と外側 エッジが一致するような画素の数が最大になるように 外側エッジを検出するための微分画像に対する閾值と, 背景と顔領域を分離するための原画像に対する閾值と を最適化する．この方法は無地な背景からどのような 絵柄を持つかが未知であるような物体を高速に抽出す るのに適した一般的な手法である. 文献 5)ではすべて のエッジを対象としているが本稿では外側エッジだけ を対象としており,すべての閾值に対して実際に 2 值 化を行わなくても外側エッジである画素の数を算出で きるアルゴリズムを提案したことが新しい．このアル ゴリズムによれば画像の画素数に比例する少ない演算 量で閾值を決定できる. 次に, 2 回目の 2 值化処理は, 顔の内部では瞳部分におけるエッジ強度が強いことが 期待されるので文献 5) の方法を適用することとした.

以下, 2 章では PICASSO の概要, 3 章では外側エッ ジと 2 值画像の境界ができるだけ一致するような 2 值 化処理によって顔領域を高速に抽出する方法, 4 章で はHough 変換と後処理によって瞳を抽出する方法に ついて述べる。また，5章では実験によって本手法の 有効性を確認し，6 章では本稿の結論をまとめるとと もに, 今後の課題について述べる.
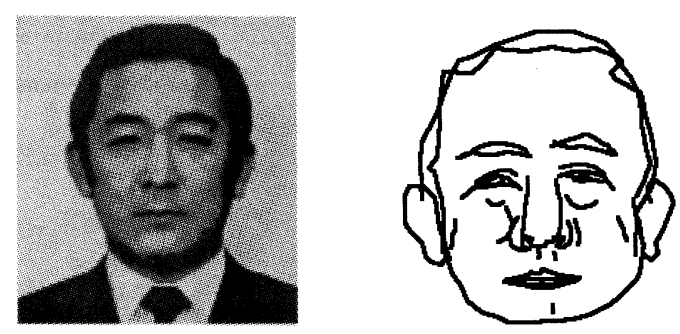

図 1 似顔絵の一例

An example of facial caricature.

\section{PICASSO の概要}

筆者らが開発中の似顔絵師システム PICASSO で は, 顔をパターン平面上の $x-y$ 座標値 $\left(x_{i}, y_{i}\right)(i=$ $1, \cdots, N)$ で表現し，これらを直線で結び, 線画とし て顔を生成・表現している. 入力顔 $P$, および, ある 参照となる顔 (= 基準顔) $R$ を与え, 誇張率 $b$ を用 いた次式

$$
\left\{\begin{array}{l}
x_{i}^{(Q)}=x_{i}^{(P)}+b\left(x_{i}^{(P)}-x_{i}^{(R)}\right) \\
y_{i}^{(Q)}=y_{i}^{(P)}+b\left(y_{i}^{(P)}-y_{i}^{(R)}\right)
\end{array}\right.
$$

の変形 (中割り法) により, 似顔絵 $Q$ を生成する. 誇 張率 $b$ を増加させるに従い, 顔の個人性特徵をより誇 張した似顔絵が得られる. 図 1 亿似顔絵の一例を示す。

\section{3. 外側エッジの情報を利用した 2 值化閾値 選択アルゴリズム}

無地の背景から未知の絵柄を持つ物体を抽出する方 法として外側エッジを利用する方法 ${ }^{4}$ が提案されてい る. 外側エッジとは微分画像を左右（上下）の両端か ら水平 (垂直) 方向に画像を走查したときに, 最初に あらかじめ定めた閾值 $t$ 以上となる画素である. 背景 が完全に一様であれば充分小さい閾值 $t$ で検出され る外側エッジが物体の輪郭と一致するので, 外側エッ ジを利用することによって容易に物体の輪郭が抽出で きる。

しかし, 無地の背景の前に物体を置いて入力した画 像でも, 様々な要因でノイズが重畳するため背景は完 全に一様とはならない.したがって, 両端から画像を 走査したとき, 閾值 $t$ が小さ過ぎると物体の輪郭に到 達する前に閾值 $t$ 以上である画素に遭遇する確率が高 くなり, 物体の輪郭で外側エッジを検出する確率が低 くなる.一方, 閾值 $t$ が高くなると, 背景のノイズが 外側エッジとして検出される確率は低くなるが, 物体 の絵柄が未知であるような場合には，画像を走査した ときに物体の輪郭も通過してしまう確率が高くなって 
しまう. 最適な閾値を決定するために文献 4)では，(1) 背景に重疊する雑音が正規白色雑音でありその分散が 既知であること，(2) メディアンフィル夕によってそれ らの雑音を低減化すること, および，(3) 画像の端か ら物体の輪郭までの距離の平均值が既知であることと いう 3 つの条件を前提として, 物体の輪郭の上で外側 エッジが検出される確率があらかじめ定めた值以上に なるような最小の閾值 $t$ を算出する方法が提案された. しかし, 多くの前提条件を満足させる必要があるため に巾広い状況の下で利用するのは容易でなかった．

そこで, 本稿では, 物体の輪郭が原画像をある閾値 $s$ で 2 值化したときの境界に含まれるような場合を想 定し，外側エッジと画像を 2 值化したときの境界がで きるだけ一致するような微分画像に対する閾值 $t$ と原 画像に対する閾值 $s$ を選択するアルゴリズムを提案す る.すなわち, 閾值 $t$ で抽出される外側エッジの集合 $E_{\text {out }}(t)$ と閾值 $s$ で入力画像 $I(i, j)$ を 2 值化した時 の境界の集合 $B(I, s)$ の一致の度合い $C_{\text {out }}$ を

$$
C_{\text {out }}=N\left(E_{\text {out }}(t) \cap B(I, s)\right)
$$

で定義し，この評価值が最大になるように閾值 $t$ と閾 值 $s$ を選択する.ここで $N(S)$ は集合 $S$ の要素の数 である。この式の右辺は外側エッジでありかつ 2 值化 した時の境界であるような画素の総数を表している. なお, エッジと 2 值画像の境界をできるだけ一致させ る文献 5)の方法では, エッジかつ境界である画素の総 数をエッジまたは境界であるような画素の総数で正規 化したものを評価值としているが，ここではそのよう な正規化は行っていない. その理由は, 微分画像を 2 值化する閾值 $t$ が減少してゼロに近くなるとほとんど の画素がエッジとなり, その結果, 正規化しない場合 には $t$ がゼロのときに評価值が最大になってしまうの に対し, 外側エッジの数は内部のエッジの数を含まな いので, $t$ がゼロに近くなっても外側エッジの位置が 外側にずれるだけで, その数は変化しないからである.

(2) 式を評価するひとつの方法は, すべての閯值 $t$ に対して外側エッジを検出し, また, すべての闇值 $s$ に対して原画像を 2 值化して境界を検出した後, す べての閾值の組合せ $(t, s)$ に対して一致の度合いを算 出することである.この方法では, 外側エッジの検出 と境界検出の処理を濃度レベル数の 2 乗回行う必要が あるため, 演算量が膨大となる。本章では, 以下, (2) を画像の画素数に比例するオーダで評価する方法を述 べる.

まず，外側エッジと境界を以下のように定義する． まず, 閾值 $s$ で画像 $I$ を 2 值化して得られる 2 值

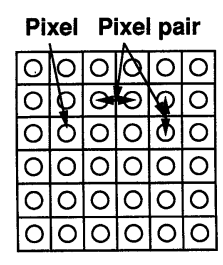

(a)

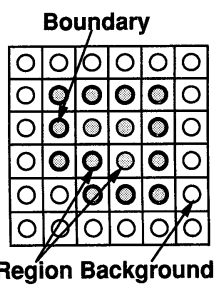

(b)

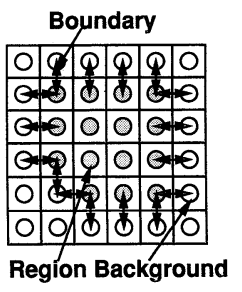

(c)
図 2 定義の概略図

Schematic description of definitions.

画像において，值が 1 である画素の集合を領域，值 が 0 である画素の集合を背景と定義する. 従来, 2 值画像の境界（boundary）は図 2(b)に示すように背 景（background）に隣接した領域（region）の画素 (pixel) として定義されていた。この定義は領域と背 景の間で対称ではないので, 図 2 (a) に示すように隣 接する 2 つの画素の画素対（pixel pair）の特徵とし て境界を定義することとした，具体的には，画素対 $b_{v}(i, j)$ を横方向に隣接した画素 $(i, j)$ と $(i+1, j)$ の 対として定義し，画素対 $b_{h}(i, j)$ を縦方向に隣接した 画素 $(i, j)$ と $(i, j+1)$ の対として定義する. 以上の 定義の基で, ここでは, 2 值画像において, 一方の画 素が領域に属し, 他方が背景に属するような画素対を 境界と呼ぶことにし, 閾值 $s$ で 2 值化した画像の境 界の集合を $B(I, s)$ で表すことにする。また，濃淡画 像において, 一方の画素の画素値と他方の画素の画素 值の差が閾值 $t$ 以上であるような画素対をエッジと呼 び, 垂直方向のエッジの集合を $E_{v}$ と水平方向のエッ ジの集合 $E_{h}$ と表すことにする.つまり

$$
\begin{aligned}
& E_{v}=\left\{\begin{array}{ll}
b_{v} \mid & |I(i, j)-I(i+1, j)| \geqq t
\end{array},\right. \\
& E_{h}=\left\{b_{h}|| I(i, j)-I(i, j+1) \mid \geqq t\right\}
\end{aligned}
$$

と定義する。ここで， $E_{v}$ を定義する式の右辺におい て, $i$ は 1 から画像の水平サイズより 1 小さい数まで の整数であり, $j$ は 1 から画像の垂直サイズ以下の整 数である。また， $E_{h}$ を定義する式の右辺において，i は 1 から画像の水平サイズまでの整数であり, $j$ は 1 から画像の垂直サイズより1小さい数までの整数で ある。一方, 外側エッジの集合 $E_{\text {out }}$ は左側エッジの 集合 $E_{l e f t}$, 右側エッジの集合 $E_{\text {right }}$, 上側エッジの 集合 $E_{u p}$, 下側エッジの集合 $E_{\text {down }}$ から構成される. $E_{l e f t}$ は画像の左端から水平に画像を走査したときに 最初にぶつかる垂直方向のエッジの集合である，ただ し，ある走査線において垂直方向のエッジが 1 つしか 存在しない場合はそのエッジは $E_{l e f t}$ の要素とはみな 
さない.つまり, 左側エッジ $E_{l e f t}$ の要素と右側エッ ジ $E_{\text {left }}$ の要素は常に対になっていることを要請する. ここではこれらのエッジの間に内部領域が存在するこ とを想定している。すなわち， $E_{l e f t}$ は次式で定義さ れる。

$$
\begin{aligned}
E_{l e f t}=\{ & b_{v}(i, j) \mid b_{v}(i, j) \in E_{v}, \\
& \forall i^{\prime}<i \quad b_{v}\left(i^{\prime}, j\right) \notin E_{v}, \\
& \text { and } \left.\exists \tilde{i}>i \quad b_{v}(\tilde{i}, j) \in E_{v}\right\}
\end{aligned}
$$

右，上，下側エッジの集合も同様に定義する.

次に，(2) 式を評価する方法であるが，その準備 として, まず, 閾值 $s$ で 2 值化した時の境界の総 数 $N(B(I, s))$ を算出する方法について述べる. 境界 の集合 $B(I, s)$ は垂直な境界から成る集合 $B_{v}(I, s)$ と水平な境界から成る集合 $B_{h}(I, s)$ 加ら構成され, $N(B(I, s))=N\left(B_{v}(I, s)\right)+N\left(B_{h}(I, s)\right)$ である.ま ず， ある画素対 $b_{v}(i, j)$ が境界である必要充分条件は その画素対の一方の 1 つが $s$ より大きいか等しく, 他 方の画素が $s$ より小さいことであることに注意する. この条件は

$$
\begin{aligned}
& \max \{I(i, j), I(i+1, j)\} \geqq s \\
& \text { and } \min \{I(i, j), I(i+1, j)\}<s
\end{aligned}
$$

と等価である。ただし, $\max \{x, y\}$ は $x$ と $y$ の最 大值を表し, $\min \{x, y\}$ は $x$ と $y$ の最小值を表す. $I_{\max }(i, j)=\max \{I(i, j), I(i+1, j)\}, I_{\min }(i, j)=$ $\min \{I(i, j), I(i+1, j)\}$ と表せば, 垂直な境界の数は

$$
\begin{gathered}
N\left(B_{v}(I, s)\right) \\
=N\left(\left\{b_{v} \mid I_{\max }(i, j) \geqq s\right\}\right. \\
\left.\cap\left\{b_{v} \mid I_{\min }(i, j)<s\right\}\right) \\
=N\left(\left\{b_{v} \mid I_{\max }(i, j) \geqq s\right\}\right. \\
\left.\cap \neg\left\{b_{v} \mid I_{\min }(i, j) \geqq s\right\}\right)
\end{gathered}
$$

で算出できる.ここで, $I_{\max }(i, j)>I_{\min }(i, j)$ なの で, $\left\{b_{v} \mid I_{\max }(i, j) \geqq s\right\} \supseteqq\left\{b_{v} \mid I_{\min }(i, j) \geqq s\right\}$ であ ることに注意すると

$$
\begin{aligned}
N\left(B_{v}(I, s)\right)= & N\left(\left\{b_{v} \mid I_{\max }(i, j) \geqq s\right\}\right) \\
& -N\left(\left\{b_{v} \mid I_{\min }(i, j) \geqq s\right\}\right)
\end{aligned}
$$

が得られる。

(7) 式から, $N\left(B_{v}(I, s)\right)$ は次のように算出され る. $\operatorname{hist}\left(s ; I_{\max }\right)$ を $I_{\max }(i, j)=s$ であるような垂
直画素対の数とする. $h i s t\left(s ; I_{\max }\right)$ は $I_{\max }$ のヒスト グラムにおいて濃度 $s$ に対応する度数を表している. このとき, $I_{\max }(i, j) \geqq s$ であるような画素対の数は, $\operatorname{hist}\left(s ; I_{\max }\right)$ を $s$ の值が大きい方から累積すること によって計算される。その累積ヒストグラムの $s$ にお ける度数を $\operatorname{chist}\left(s ; I_{\max }\right)$ と表すと

$$
N\left(B_{v}(I, s)\right)=\operatorname{chist}\left(s ; I_{\max }\right)-\operatorname{chist}\left(s ; I_{\min }\right)
$$

が得られる。このようにして, 垂直方向の境界の総数 は, 実際にそれぞれの閾值 $s$ に対して境界を抽出しな くても $I_{\max }, I_{\min }$ の累積ヒストグラムから算出でき る.したがって, 必要とされる計算量のオーダは画像 の画素数に比例する. 水平方向の境界についても同様 である。

次に, 外側エッジの数 $N\left(E_{\text {out }}(t)\right)$ を算出する方法 について述べる。外側エッジも垂直な成分と水平な成 分から成り, $N\left(E_{\text {out }}(t)\right)=N\left(E_{\text {outv }}\right)+N\left(E_{\text {out } h}\right)$ で ある。これらを評価するために, $I^{v}(i, j)$ を

$$
\begin{aligned}
& I^{v}(i, j)=\min \\
& \left\{\max \left\{\left|I\left(i^{\prime}, j\right)-I\left(i^{\prime}-1, j\right)\right| ; i^{\prime} \leqq i\right\},\right. \\
& \left.\max \left\{\left|I\left(i^{\prime}, j\right)-I\left(i^{\prime}+1, j\right)\right| ; i^{\prime} \geqq i\right\}\right\}
\end{aligned}
$$

によって定義する．ここで, $\left\{\max \left\{\mid I\left(i^{\prime}, j\right)-I\left(i^{\prime}-\right.\right.\right.$ $\left.\left.1, j) \mid ; i^{\prime} \leqq i\right\}\right\}$ は画素 $(i, j)$ より左側の画素における 微分の絶対值 $\left|I\left(i^{\prime}, j\right)-I\left(i^{\prime}-1, j\right)\right|$ の最大值を表 す.（3），(4)，(5) 式から容易にわかるように，ある画 素対 $b_{v}(i, j)$ が閾值 $t$ に対する外側エッジであるため の必要充分条件は, その画素対が $I^{v}(i, j)$ を閾值 $t$ で 2 值化して得られる 2 值画像の境界であることである したがって（8）式を導いたときと同様にして

$$
\begin{aligned}
N\left(E_{\text {out } v}(t)\right)= & \operatorname{chist}\left(t ; I_{\text {max }}^{v}\right) \\
& -\operatorname{chist}\left(t ; I_{\text {min }}^{v}\right)
\end{aligned}
$$

によって外側エッジの総数が算出できる. 水平な外側 エッジについても同様である.

最後に, 外側エッジかつ境界である画素対の数 $N\left(E_{\text {out }}(t) \cap B(I, s)\right)$ を得る方法について述べる. 垂 直な外側エッジは $I^{v}$ の境界であるから

$$
\begin{aligned}
& N\left(E_{\text {out } v}(t) \cap B(I, s)\right) \\
& \quad=N\left(B_{v}\left(I^{v}, t\right) \cap B_{v}(I, s)\right)
\end{aligned}
$$

である.（6）式と同様に（11）式の右辺は

$$
N\left(B_{v}\left(I^{v}, t\right) \cap B_{v}(I, s)\right)
$$




$$
\begin{aligned}
= & N\left(\left\{b_{v} \mid I_{\max }^{v}(i, j) \geqq t\right\}\right. \\
& \cap \neg\left\{b_{v} \mid I_{\min }^{v}(i, j) \geqq t\right\} \\
& \cap\left\{b_{v} \mid I_{\max }(I ; i, j) \geqq s\right\} \\
& \left.\cap \neg\left\{b_{v} \mid I_{\min }(i, j) \geqq s\right\}\right)
\end{aligned}
$$

と表される. $\left\{b_{v} \mid I_{\max }(i, j) \geqq s\right\} \supseteqq\left\{b_{v} \mid I_{\min }(i, j) \geqq\right.$ $s\},\left\{b_{v} \mid I_{\max }^{v}(i, j) \geqq t\right\} \supseteqq\left\{b_{v} \mid I_{\text {min }}^{v}(i, j) \geqq t\right\}$ であ るから

$$
\begin{gathered}
N\left(B_{v}\left(I^{v}, t\right) \cap B_{v}(I, s)\right) \\
=N\left(\left\{b_{v} \mid I_{\max }^{v}(i, j) \geqq t\right\}\right. \\
\left.\cap\left\{b_{v} \mid I_{\max }(i, j) \geqq s\right\}\right) \\
+N\left(\left\{b_{v} \mid I_{\min }^{v}(i, j) \geqq t\right\}\right. \\
\left.\cap\left\{b_{v} \mid I_{\min }(i, j) \geqq s\right\}\right) \\
-N\left(\left\{b_{v} \mid I_{\max }^{v}(i, j) \geqq t\right\}\right. \\
\left.\cap\left\{b_{v} \mid I_{\min }(i, j) \geqq s\right\}\right) \\
-N\left(\left\{b_{v} \mid I_{\min }^{v}(i, j) \geqq t\right\}\right. \\
\left.\cap\left\{b_{v} \mid I_{\max }(i, j) \geqq s\right\}\right)
\end{gathered}
$$

となる.(8) 式を導出したときと同様に, $I_{\max }(i, j)=s$, $I_{\text {max }}^{v}(i, j)=t$ であるような垂直画素対の数を表す 2 次元ヒストグラム $h i s t \_2\left(s, t ; I_{\max }, I_{\text {max }}^{v}\right)$ を導入 する.このとき, $N\left(\left\{b_{v} \mid I_{\text {max }}^{v}(i, j) \geqq t\right\} \cap\left\{b_{v} \mid\right.\right.$ $\left.\left.I_{\max }(i, j) \geqq s\right\}\right)$ は hist_2 $\left(s, t ; I_{\max }, I_{\text {max }}^{v}\right)$ を值が大 きい方からから累積することによって算出される 2 次

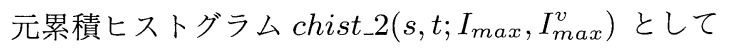
得られる.よって

$$
\begin{aligned}
& N\left(B_{v}\left(I^{v}, t\right) \cap B_{v}(I, s)\right) \\
& =\operatorname{chist}_{2} 2\left(s, t ; I_{\max }, I_{\max }\right) \\
& + \text { chist_2 }\left(s, t ; I_{\text {min }}, I_{\text {min }}^{v}\right) \\
& \text {-chist_2(s, } \left.t ; I_{\max }, I_{\min }^{v}\right) \\
& \text {-chist_2 }\left(s, t ; I_{\min }, I_{\max }^{v}\right)
\end{aligned}
$$

$N\left(B_{h}\left(I^{h}, t\right) \cap B_{h}(I, s)\right)$ も同様にして得られる. した がって, $N\left(E_{\text {out }}(t) \cap B(I, s)\right)$ は 2 次元累積ヒストグ ラムを計算すれば得られる。

以上の議論から,(2) 式の評価関数は画像の画素数に 比例する低い計算コストで計算されることが示された。

\section{4. 瞳抽出アルゴリズム}

\section{1 概 要}

今回開発した瞳抽出アルゴリズムは図 3 に示すように $「$ 前処理部 (preprocessing)」, $「$ Hough 変換部 (Hough transform) $\lrcorner,\ulcorner$ 後処理部 (postprocessing) $\lrcorner, の 3 つ$

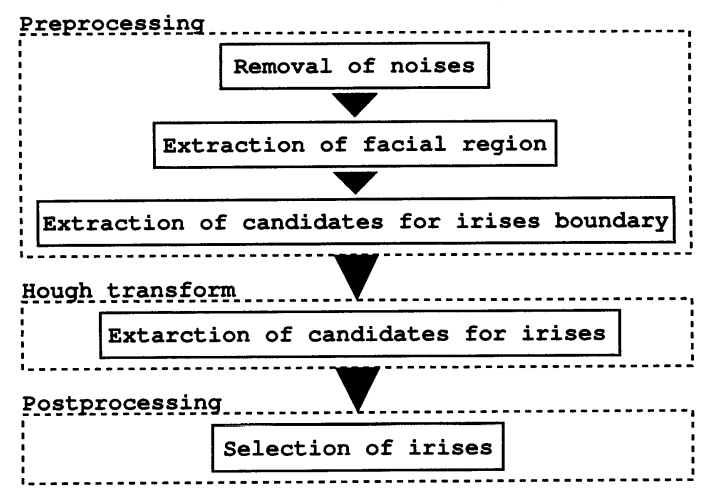

図 3 瞳抽出アルゴリズムの流れ

Processing flow of the extraction of irises.

の処理部からなる、「前処理部」ではまず，背景から外 側エッジの情報を利用した閾值処理によって顔領域を 抽出し, 次に, 顔領域を対象として再び閾值処理を行 う. そして, 2 回目の閾値処理における図と地の境界 を瞳境界候補として抽出する。なお，1回目の閾值処 理は顔輪郭に関する初期記述生成を行っていることに 相当する. 次に, $\ulcorner$ Hough 変換部」で円の Hough 変換 を適用し，瞳の候補を抽出する，最後に，「後処理部」 で瞳の位置関係を基にした条件を設定し，その条件に あったものを瞳の候補から選択・抽出する．以下に各 処理部の詳細を説明する。

\section{2 前処理部}

まず, $5 \times 5$ のメディアンフィルタ処理 (removal of noises）を原画像に対して行い, 前章で提案した外側 エッジの情報を利用した 2 值化閾値処理を施したあと， 穴埋めの処理を行って顔領域を抽出する(extraction of facial region).

次に, 抽出された顔領域のみに対して濃淡画像の処 理領域を限定し, 文献 5)で述べられた閾值処理アルゴ リズムで 2 值化閾值処理を行う。このとき抽出された 2 值画像で最大面積である髪領域を削除し, 残りの部 分の境界を抽出し，これを瞳境界候補 (extraction of candidates for irises boundary) とする.

\subsection{Hough 変換部}

まず簡単に, 円の Hough変換の原理について述べる.

エッジ画像上のあるエッジ点 $\left(x_{i}, y_{i}\right)(i=1,2, \ldots)$ を円周上に持つ円群は, パラメー夕空間 $(a, b, r)$ にお いてはエッジ点の座標が中心となる式

$$
\left(a-x_{i}\right)^{2}+\left(b-y_{i}\right)^{2}=r^{2}
$$

の円の集合として表され, 最も多くのエッジ点を通過 する円を求めたい場合, エッジ点ごとにパラメータ空 
間内に円錐を描き, これらの円錐面の交差の度数を数 え, その度数のピークを見つければ目的の円を求める ことができる。

すなわち, 投票度数が最大となるパラメータの組 $\left(a_{0}, b_{0}, r_{0}\right)$ を求めた後

$$
\left(x-a_{0}\right)^{2}+\left(y-b_{0}\right)^{2}=r_{0}^{2}
$$

のような中心 $\left(a_{0}, b_{0}\right)$, 半径 $r_{0}$ の円を描けぼ, 結果的 にこれが最も多くのエッジ点を通過する円となってい る. 本研究の場合, このようにして求めた上位の円が 瞳の候補となる。

「前処理部」で抽出した瞳境界候補に対して円の Hough 変換を適用し, 瞳候補を抽出する (extraction of candidates for irises).ここで, 円の Hough 変換 の適用後, パラメー夕空間において投票度数が極大に なっており, かつ, 投票度数がある閾值以上であるパ ラメータを瞳候補として検出する。なお, 顔領域を中 心線で左右に分離し, 瞳候補は左右のそれぞれの領域 において独立に検出する。

\section{4 後処理部}

前述の処理によって, 顔領域の中心線で分けられる 左右の領域のそれぞれにおいていくつかの瞳の候補が 検出されるが, 左右の領域のそれぞれから 1 つずつ選 んだ瞳候補の対の中から最も確からしい対を選択す る (selection of irises).このとき, 以下の事実に留 意する.

・左右の瞳はほぼ水平に位置する. 左右の瞳候補の 垂直距離の上限を dist $_{t h}$ とする.

・左右の瞳の半径はおおむね同じである. 半径の差 の上限を $\operatorname{radi}_{t h}$ とする.

・2つの瞳候補の水平距離が実際の瞳の水平距離よ り $\alpha$ 以上小さくなることは経験的にほとんどない.

最も確からしい対の選択は次のような手順で行う.

（1）左右の領域のそれぞれにおいて少なくとも 1 つの瞳の候補が存在するような投票度数の中で 最大の度数を $k$ とする.

（2）投票度数が $k$ 以上である円を瞳の候補として 抽出する。

（3）左右の領域のそれぞれから 1 つずつ候補を 選択して得られる円の対すべてのリストを作成 する.

(4) 左右の円の半径の差がある閾值 $\mathrm{radi}_{t h}$ 以上 ならリストから削除する。

（5）左右の円間の垂直距離の差がある閾值 $d^{2} i s t_{t h}$ 以上のものをリストから削除する。

（6）左右の円間の水平距離 $x_{l r}$ が最小であるもの

$$
\begin{aligned}
& \left(x_{\min }\right) \text { を求め } \\
& x_{l r} \geqq x_{\min }+\alpha \\
& \text { ただし }, \alpha \text { は定数值 }
\end{aligned}
$$

を満たすものをリストから削除する。

（7）もし，この時点でリストに円の対の候補が 1 つだけ残っているならば，それを左右の瞳とし て抽出する。また, 複数の円の対が残っている ならぼ，ほぼ等しいものとしてその中から任意 の対を選び，それを左右の瞳として抽出する。 また，すべての円の対の候補がリストから削除 されていたなら， $k=k-1$ とし，(2) へ戻る.

\section{5. 実験と考察}

原画像は白色無地の背景の基で撮影した $640 \times 480$ ， 8 ビットの濃淡画像 30 枚である. 正面から照明を施し, 眼鏡は外してある。

\section{1 外側エッジを利用した顔領域抽出処理}

図 4 に原画像の一例，それに対して $5 \times 5$ のメディ アンフィルタを施した後, 3 章で述べた方法によって 2 值化した.

メディアンフィルタ処理後の画像のヒストグラムを 図 5 に示す. 図中, 矢印 (a) は大津の方法 ${ }^{6)}$, 矢印 (b) は文献 5) の方法, 矢印 (c) は 3 章で述べた方法によっ て選択した閾值を示す。また，それぞれの方法で 2 值 化した結果を図6,図 7 , および, 図 8 に示す。図 8 に 対して穴埋め処理をした後, 面積が最大である領域を 抽出した結果が図 9 である.

図 6 と図 8 とを比較すると, 大津の方法では原画像 を 2 值画像によってできるだけ忠実に表現するという 観点では優れているが，耳の一部分が欠けている。一 方, 提案した手法では顔の内部の構造が失われている が, 実際の顔の輪郭のすべてが 2 值化した画像の境界

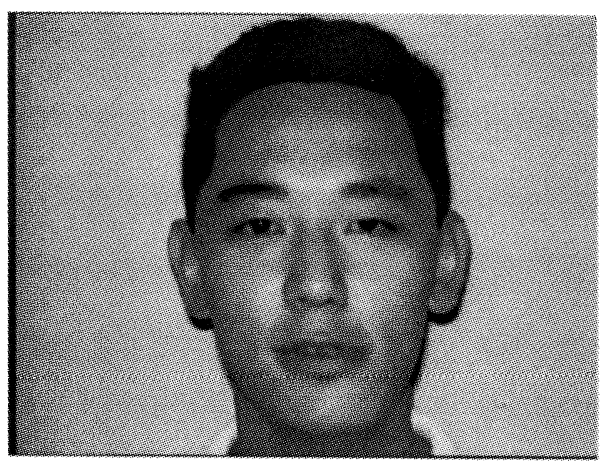

図 4 原画像 Original image. 


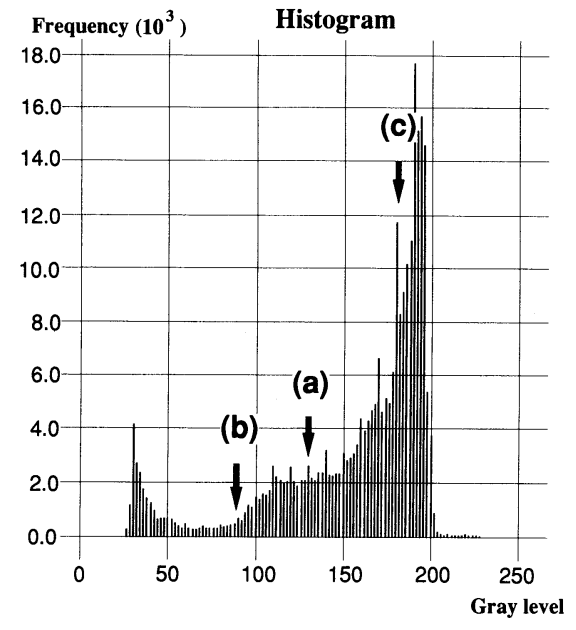

図 5 ヒストグラム

Histogram.

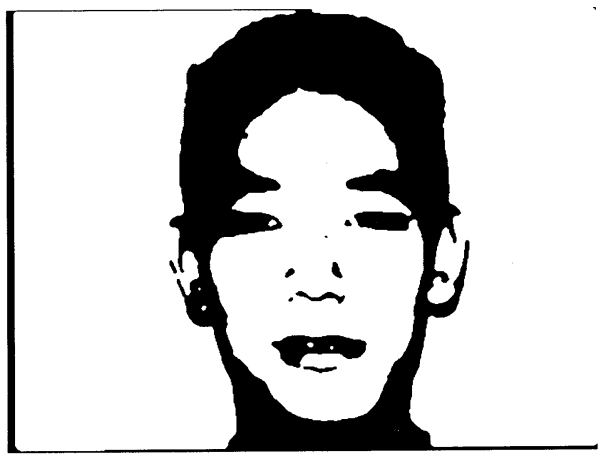

図 6 大津の方法による 2 值化画像

Binary image obtained by the Ohtsu's method.

の一部になっている，2 章で述べたように似顔絵生成 の過程で誇張処理を行うので, 耳の一部が欠けている だけでもそれが誇張されてしまい, 高品質の似顔絵が 生成できなくなる。それに対して, 提案した手法では, 実際の顔の輪郭のすべてが 2 值化した画像の境界に含 まれているので, 生成された 2 值画像を基に穴埋めな どの処理によって似顔絵に適した顔領域の抽出が可能 であることがわかる。このような観点から，実際の顔 の輪郭のすべてが 2 值画像の境界の一部になっている ときにこの 2 值化処理は成功したとみなすと, この基 準の下で，大津の方法では 30 枚の画像に対して 8 枚 成功したのに対して, 提案手法では 30 枚すべてが成 功であった。この結果から提案手法が似顔絵生成シス テムにおける顔領域抽出手法として有効であることが 確認された.

一方, エッジと 2 值画像の境界の一致度を評価値と 論 文 $\square$ 似顔絵生成のための顔と瞳の輪郭抽出方式

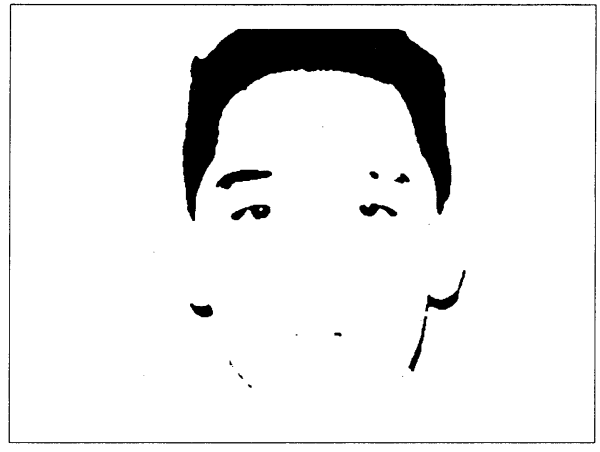

図 7 文献 5) による2 值化画像

Binay image by the method in ref.5).

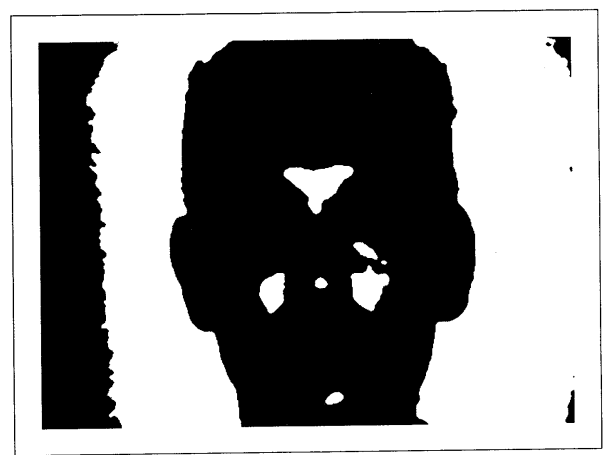

図 8 提案手法による 2 值化画像

Binary image obtained by the proposed method.

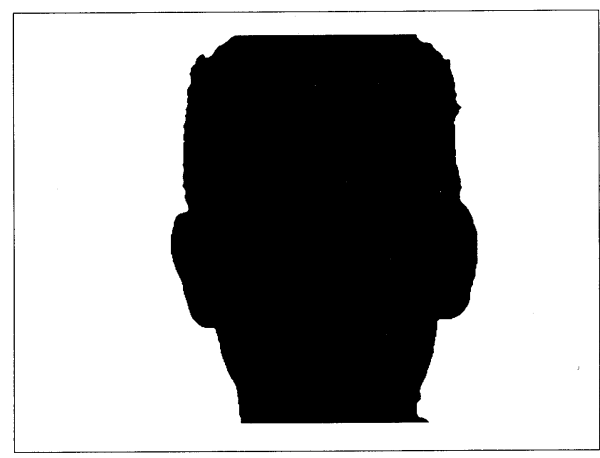

図 9 顔領域の抽出

Extracted facial region.

する文献 5) の方法では，顔内部の髪部分と肌の境界や 瞳の輪郭部分に強いエッジが存在するために, その部 分が境界となるように閾值が選択されている。この傾 向は残りの 29 枚の画像でも同様であった。このこと から，無地の背景の基で撮影した画像から顔の輪郭を 抽出する目的のためには，すべてのエッジに着目する のは適当ではなく, 外側エッジに着目する手法が有効 


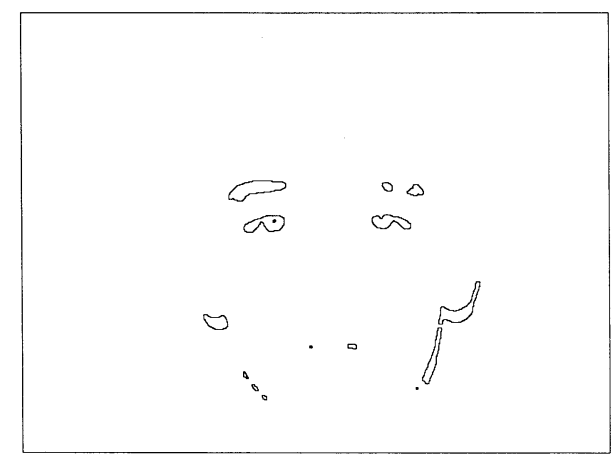

図 10 瞳境界候補の抽出 Candidates for irises boundary.

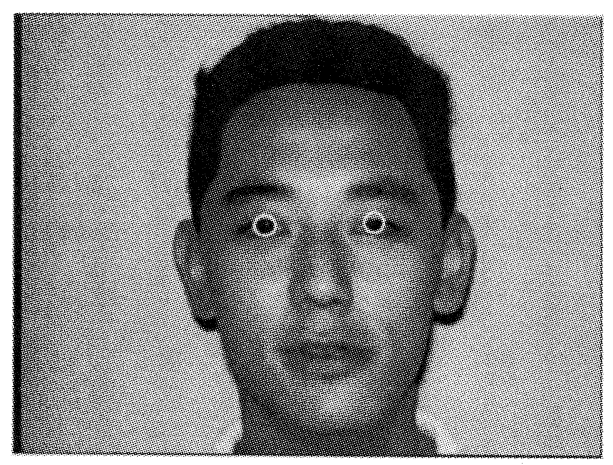

図 11 認識された瞳 Recognized irises.

表 1 後処理の経過（1） Post processing (1).

\begin{tabular}{|c|c|c|c|}
\hline \multirow{3}{*}{ 左目 } & & $x$ & 272 \\
\hline & & ? & 227 \\
\hline & $y$ & $r$ & 11 \\
\hline 390 & 223 & 11 & 000 \\
\hline 409 & 234 & 12 & $00 \times$ \\
\hline
\end{tabular}

であることがわかる。

\subsection{Hough 変換と後処理による瞳抽出処理}

顔領域内において文献 5) の方法によって再び 2 值化 した画像の境界を図 10 に示す。また，それに対して円 の Hough 変換抢よび後処理を施して瞳を抽出した結 果を図 11 に示す．瞳がまぶたによって半分ほど隠され ていても，瞳がうまく抽出されていることがわかる．

本例では, Hough 変換部で抽出された瞳候補の中か ら, 左瞳候補が 2 個，右瞳候補が 1 個抽出された。こ れらの候補から後処理によって最適なものが選ばれる 過程を表 1 に示す. 表中 $x, y, r$ はそれぞれ円の中心座 標と半径（画素単位）を表す．表の各項における○や
表 2 後処理の経過 (2); 1 度目の試行 Post processing (2); the first trial.

\begin{tabular}{|c|c|c|c|c|}
\hline & & & 268 & 268 \\
\hline 左目 & & & 229 & 232 \\
\hline$x$ & y & $r r$ & 11 & 9 \\
\hline 381 & 414 & 11 & $0 \times$ & $\times$ \\
\hline 393 & 242 & 12 & $O x$ & $\times$ \\
\hline
\end{tabular}

表 3 後処理の経過 (2)；2 度目の試行 Post processing (2); the second trial.

\begin{tabular}{|c|c|c|c|c|c|}
\hline \multirow{2}{*}{ 左目 } & \multirow[b]{3}{*}{$y$} & 目 $\quad x$ & 203 & 268 & 268 \\
\hline & & $u$ & 308 & 229 & 232 \\
\hline$\underline{x}$ & & $r \quad r$ & 12 & 11 & 9 \\
\hline 376 & 419 & 11 & $O x$ & $O \times$ & $x$ \\
\hline 381 & 414 & 11 & $O x$ & $O x$ & $\bar{x}$ \\
\hline 383 & 411 & 11 & $O x$ & $0 \times$ & $x$ \\
\hline 384 & 410 & 11 & $O x$ & $O x$ & $\times$ \\
\hline 393 & 242 & 12 & $O \times$ & $0 \times$ & $x$ \\
\hline
\end{tabular}

表 4 後処理の経過 (2)；3 度目の試行 Post processing (2); the third trial.

\begin{tabular}{|c|c|c|c|c|c|c|}
\hline \multirow{2}{*}{ 左目 } & \multirow[b]{3}{*}{$u$} & \multirow{2}{*}{ 自 $\quad \begin{array}{l}x \\
\end{array}$} & 203 & 248 & 268 & 268 \\
\hline & & & 308 & 239 & 229 & 232 \\
\hline$x$ & & $r$ & 12 & 12 & 11 & 9 \\
\hline 375 & 232 & 10 & $x$ & $x$ & 000 & 000 \\
\hline 375 & 234 & 9 & $\times$ & $x$ & $x$ & 000 \\
\hline 376 & 419 & 11 & $O \times$ & $O x$ & $O x$ & $x$ \\
\hline 381 & 414 & 11 & $O \times$ & $O x$ & $O x$ & $\times$ \\
\hline 383 & 411 & 11 & $O \times$ & $O x$ & $O x$ & $x$ \\
\hline 384 & 410 & 11 & $O \times$ & $O x$ & $O x$ & $\times$ \\
\hline 389 & 401 & 9 & $\times$ & $\times$ & $\times$ & $O \times$ \\
\hline 393 & 242 & 12 & $O \times$ & $00 \times$ & $O x$ & $\times$ \\
\hline 399 & 389 & 9 & $x$ & $\times$ & $\times$ & $O x$ \\
\hline
\end{tabular}

×の列は, 左から順に後処理部における半径の差に対 するテスト，垂直距離に対するテスト，水平距離に対 するテストの結果を表す。これらテストにおける閾値 はそれぞれ radi $_{t h}=2$, dist $_{t h}=10, \alpha=3$ である. これらの值は経験的に適切なものを選択した。

また，○は最終的に選ばれた円の対を表している。 この例では，半径の差と垂直距離に関する最初の 2 つ のテストには両方の対が共に合格したが, 水平距離に 関するテストで下段の対が不合格となり，上段の対が 選択された。

別の例を表 2〜表 4 に示す。この例では，1 度目の 


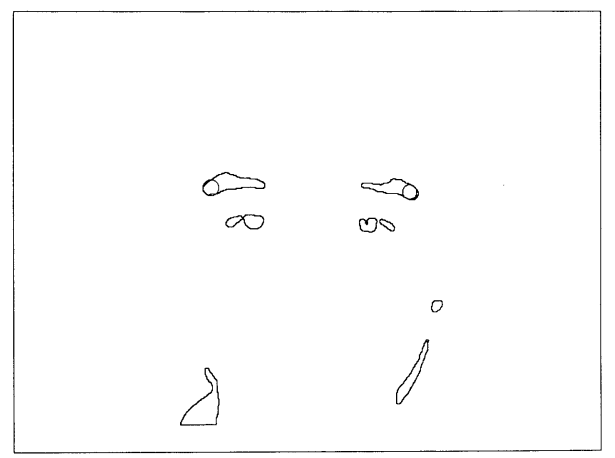

図 12 瞳抽出の失敗例

The unsuccessful case.

試行ではテストに合格する円の対が存在しなかったの で, 投票度数に対する閾值 $k$ を 1 減じて得られる $5 \times$ 3 の対に対して 2 度目の試行が行われた。しかし，こ れらの対もすべて不合格となったため,さらに投票度 数に対する閾值を 1 減じ， $9 \times 4$ の円の対に対して 3 度目の試行が行われた。その結果，3つの対がすべて のテストに合格し，そのうちから，任意に 1 つが最終 的に選択された。ここでは, 最後に合格した対を出力 している。

同様なプロセスを経て入力画像 30 枚のうち 29 枚に 対して瞳抽出処理が成功した。瞳の抽出に失敗した唯 一の例を図 12 に示す。この例では, Hough 変換にお いて向かうて右側の瞳に対応する円の投票度数よりも 眉尻の部分に対応する円の投票度数のほうが多かった ため, 後処理の結果, この眉尻が誤抽出された. 30 枚 の画像のうちこれが唯一の失敗例である.

ここで，前章の方法のロバストネスを増すために， 前章の方法とは独立した方法で目の概略位置を検出し， 前章の方法で検出した瞳が正しいかどうかを検証する プロセスを設けた ${ }^{7)}$. 具体的には，まず，顔領域にお いて，2 值化した後に境界を検出するのではなく, 微 分処理をした後に 2 值化してエッジを検出する．次に そのエッジ画像を水平方向と垂直方向に射影し，これ らの射影パターンを基に目，眉，鼻，口の概略位置を， 図 13 に口印で示すように，検出する，そして，前章の 方法によって抽出した瞳が目の位置になければ，これ らの瞳を候補から除外して前章の「後処理部」に戻り， 再度瞳の抽出を試みるようにした。この方法を用いれ ば，上記の唯一の失敗例が修復され，結果として，30 枚すべての画像の瞳が完全に抽出された．修復された 瞳の結果を図 13 に示す．なお，瞳の概略位置の検出が 間違っている可能性もあるので, Hough 変換による瞳 抽出結果と瞳の概略位置の検出に矛盾が生じたときに

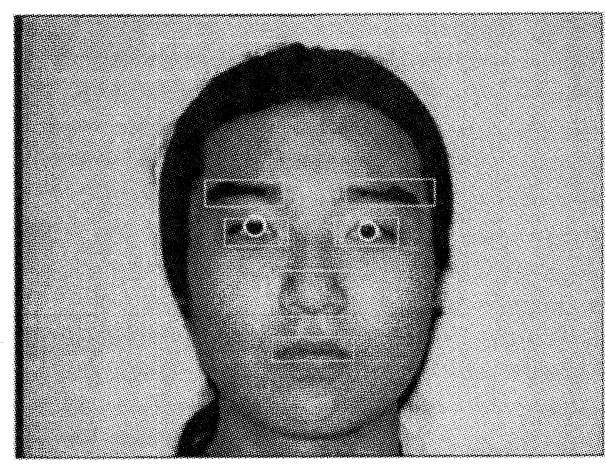

図 13 検証処理によって修復された瞳 Recovered irises by verification.

どちらを優先するかを判定する基準を設ける必要があ るが，これは今後の課題である.

\section{6. まとめと今後の課題}

本稿では，無地な背景の基で撮影した画像から顔輪 郭を抽出するための最適な閾值として, 外側エッジと 2 值画像の境界をできるだけ一致させるような閾值を 画素数に比例する少ない演算量で算出するアルゴリズ 厶を提案した。また，顔領域の内部をさらに2 值化閾 值処理を行って得られる境界に対して円の Hough 変 換を施すことによって瞳の候補を抽出し，2つの瞳の 位置関係に関する知識を利用して最適な候補を選択す る方式を提案し，その有効性を実験的に示した。また， 瞳輪郭抽出アルゴリズムに対する検証処理を設けるこ とで，瞳輪郭抽出処理をよりロバストにする可能性に ついて論じた。

今後は, 瞳輪郭抽出アルゴリズムに対する検証処理 を強化し，よりロバストな瞳輪郭抽出アルゴリズムを 作成する。また，抽出された瞳の情報を基に他のすべ ての顔部品の輪郭抽出を行い, 抽出された顔部品の輪 郭を似顔絵生成の初期記述に合うょうにリサンプリン グを行う予定である。

日頃，ご支援，ご理解をいただく関係各位に深く感 謝致します。な押，本研究の一部は，1996 年度科研費 (08207222，07680415，08780313), IMS 研究プロジェ クト「製品のライフサイクルにおける感性・官能評価 システム」による．記して感謝する。

\section{〔参 考 文 献〕}

1）村上和人, 輿水大和, 中山晶, 福村晃夫 : “錯視を用いた似顔 絵生成システム PICASSO そついて”，情処学論誌，34, 10, pp.2106-2116 (Oct. 1993)

2）村上和人，輿水大和：“似顔絵生成と表情生成の統合につい て”, テレビ誌, 50, 10, pp.1515-1521 (1996)

3）伴野, 岸野, 小林：“瞳孔の抽出処理と頭部の動きを許容す 
る視線検出装置の試作”, 信学論, J76-D-II, 3, pp.636-646 (Mar. 1993)

4) 鳥生隆, 後藤敏行, 山本栄一郎：“メディアンフィル夕特性の 解析と輪郭抽出の最適化”, 信学論, J68-D, 4, pp.489-495 (Apr. 1985)

5）鳥生隆, 岩瀬洋道, 後藤敏行: “最小值フィル夕を利用した 2 值 化のしきい值選択法”，信学論，J72-D-II, 11, pp.1800-1806 (Nov. 1989)
6）大津展之：“判別および最小 2 乗基準に基づく自動しきい值 選定法”，信学論，J63-D, 4, pp.349-356 (Apr. 1980)

7) Segawa, Y., Sakai, H., Endoh, T., Murakami, K., Toriu, T., and Koshimizu, H.: "Face Recognition Through Hough Transform for Irises Extraction and Projection Procedures for Parts Localization -for Facial Caricaturing System PICASSO-", Proc. PRICAI'96, pp.625-636 (Aug. 1996)

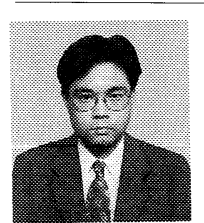

瀬川 能昭 1995 年, 中京大学情報科学 部情報科学科卒業. 1997 年, 同大学大学院 情報科学研究科修士課程修了. 同年, 富士通 (株) 入社. 画像処理, 主に顔画像処理, 顔部 品認識の研究に従事.

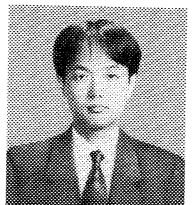

遠藤利生 1987 年, 東京大学工学部計 数工学科卒業. 同年, (株) 富士通研究所入社. 以来, 画像処理, 画像理解の研究に従事. 視 覚の計算論に興味をもつ. 工学博士.

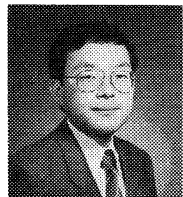

むらかみ かずひと

村上和人 1984 年, 名古屋大学理学部 物理学科卒業. 名古屋市工業研究所勤務を経 て, 1991 年, 中京大学情報科学部助手. 現在, 同講師. Hough 変換アルゴリズム, X 線画像 処理, 似顔絵生成システムなどの研究・開発 に従事.

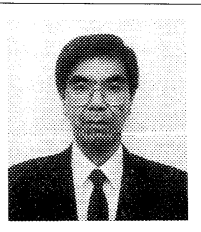

鳥生隆 1980 年, 京都大学大学院理 学研究科博士課程修了. 1982 年, (株) 富士 通研究所入社. 以来, 画像処理, 画像理解の 研究に従事. 理学博士.

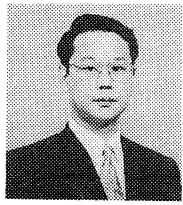

輿水大和 1975 年, 名古屋大学大学院 工学研究科博士課程修了. その後, 名古屋大 学工学部助手, 名古屋市工業研究所勤務を経 て, 1986 年より中京大学. 現在, 情報科学部 教授. 画像パターン認識, マシンビジョンの 研究に従事. 最近, 似顔絵生成など感性情報 処理, Hough 変換などに興味あり.工学博 士. 正会員. 